\title{
THE EFFECT OF HORMONE (17 $\alpha$-METHYLTESTOSTERONE, 17ß-ESTRADIOL) USAGE ON DEVELOPMENT, SEX INVERSION AND PIGMENTATION OF ELECTRIC YELLOW CICHLID (Labidochromis caeruleus FRYER, 1956)
}

\author{
KARSLI, Z $.^{*}-$ ŞAHIN, D. ${ }^{1}-$ ÖZ, M. ${ }^{2}-$ ARAL, O. ${ }^{2}$ \\ ${ }^{1}$ Vocational School, Sinop University, 57000 Sinop, Turkey \\ (phone: +90-368-271-57-38; fax: +90-368-271-57-40) \\ ${ }^{2}$ Fisheries Faculty, Sinop University, 57000 Sinop, Turkey \\ ${ }^{*}$ Corresponding author \\ e-mail: zaferkarsli@hotmail.com
}

(Received $3^{\text {rd }}$ Sep 2018; accepted $1^{\text {st }}$ Nov 2018)

\begin{abstract}
This research was designed in order to examinate the effects of $17 \alpha$-methyltestosterone and $17 \beta$-estradiol hormone use on the development, growth performance, survival, sex ratio and coloration of the electric yellow cichlid (Labidochromis caeruleus Fryer, 1956). Seven different groups were designed in the study. While no hormones were added to the control diet, 6 different rates of hormones were added to the other groups. Cichlid mean weight was determined as $0.64 \pm 0.01 \mathrm{~g}$, were stored such that three replications for each group. The fish were fed with the feeds for a period of 2 months. At the end of this research, the highest weight gain was determined in the $20 \mathrm{mg} \mathrm{kg}^{-1} 17 \alpha-\mathrm{MT}$ group $(0.39 \pm 0.17 \mathrm{~g})$. When the sex change rates were evaluated, it was determined that the feminization rates in the $17 \beta$-ES hormone group were $80.00 \%, 82.22 \%$ and $86.67 \%$, respectively, and all fishes in the $17 \alpha$-MT hormone group were $100 \%$ male. When the results of the physical color analysis were evaluated, it was determined that the

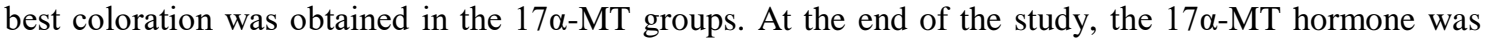
determined to have a better effect than $17 \beta$-ES hormone on the growth, feed conversation rate, sex change and pigmentation of electric yellow cichlid (Labidochromis caeruleus Fryer, 1956).
\end{abstract}

Keywords: Cichlid spp., sex hormones, growth, sex change, coloration

\section{Introduction}

The aquarium sector is an important trading area in pet hobbies that continues to grow around the world. It is estimated that the global trade value of the sector, which includes about 5300 freshwater fish and 1802 marine fish, is around \$ 15-30 billion. The major markets for trade in the aquarium sector are the US, European countries and Japan (Penning et al., 2009; Saxby et al., 2010; Rhyne et al., 2012; Raghavan et al., 2013).

In fish species, hormone applications in feed and water have different effects (growth, sex change, coloration, survival rate etc.). These differences, especially in the fish species, have been found to be due to the type of hormone used and the amounts added. The use of hormones seems to have an important place in the breeding of aquarium fish due to the fact that the fish species to be cultivated are brought to the market in a shorter period of time, the fish are consumed less by consuming less, the fish are produced in the desired sex and the positive effect on the coloring of the aquarium fish is observed (Brzuska, 1999; Pandian and Kirankumar, 2003).

One of the most important features of aquatic organisms is that they have a bright color. The reason of having a bright color, are related with feeding in their natural environment. One of the biggest problems is color loss in aquaculture. In case of this 
problem consumer demand is decrease. The feed given to these species must provide the necessary ingredients for the species to acquire the desired colours (Kop and Durmaz, 2008).

Sex steroids are important for aquarium fish production and coloration of fish. Desired sex can be supplied with these steroids by producers (Turan et al., 2003). Effects of steroid hormones on aquarium fish like as cichlid, beta, guppy, black molly, swordtail and on edible fish like as rainbow trout, salmon, sea bass, eel, carp, tilapia have been already examinated in world (Pandian and Sheela, 1995).

Labidochromis caeruleus is a species of cichlid endemic to the central western coastal region of Lake Malawi in East Africa. They prefer to live in the rocky and rocky regions of Malawi. This species can reach to a length of $15 \mathrm{~cm}(5.9 \mathrm{inch})$. In the fins of male fish, the black colors are more dense and wider, while the female have weaker and thinner black lines (Lewis, 1982; Şahin, 1999).

The use of hormones to stimulate sex change in fish, especially in the aquarium industry, has led many aquarium fish producers to pay attention to hormone use in producing expensive varieties that vary in price by sex. Especially in this species (Labidochromis caeruleus Fryer, 1956), prices are often higher because male have huge and more attractivecolors. Therefore, the aim of the this research was planned to confirm the effects of hormones on skin colouration, sex inversion and development of Labidochromis caeruleus fry.

\section{Materials and Methods}

In this study, effects of $17 \alpha-M e t i l t e s t o s t e r o n$ and $17 \beta$-Estradiol hormones on growth, development, survival rate, sex reversal and color parameters of cichlid fish (Labidochromis caeruleus Fryer, 1956) were investigated (Figure 1).

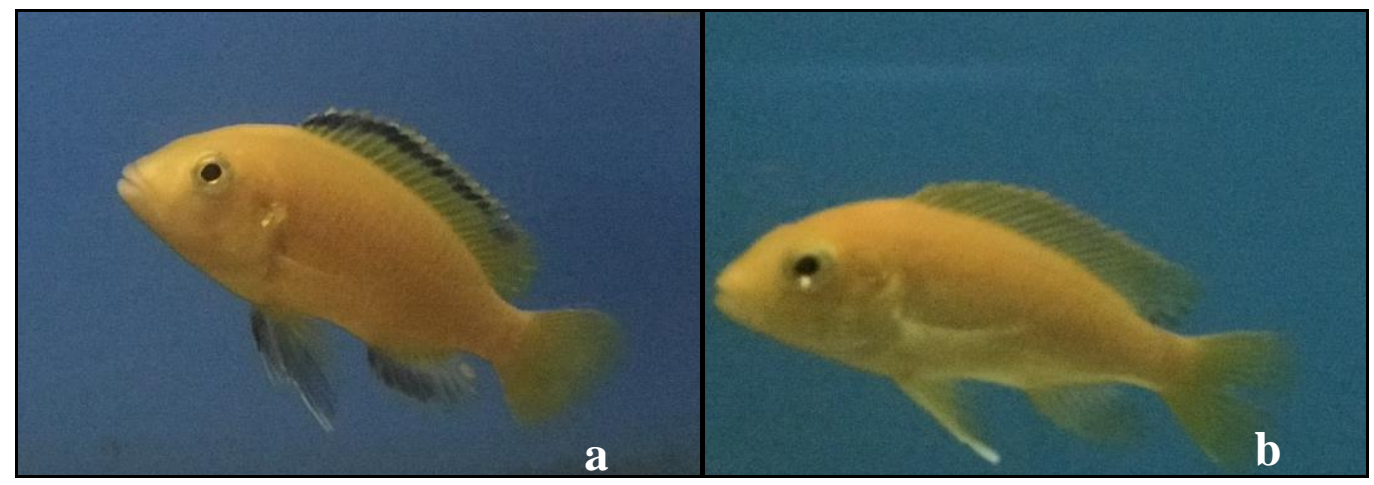

Figure 1. Male (a) and female (b) electric yellow cichlid (Labidochromis caeruleus) (Original)

$17 \alpha$-MT and $17 \beta$-ES hormones were used in this study because of they are the most effective anabolic steroids for fish (Turan et al., 2003). For this purpose, 500 fry were supplied from a commercial breeder and 315 of them were randomly selected for the experiments. The fish were individually weighed and placed into $30 \mathrm{~L}$ aquariums in groups of 15 fish in 3 replications. Throughout the experiments, water temperature was fixed at $26 \pm 1{ }^{\circ} \mathrm{C}$. Aquarium water characteristics were as follows: Dissolved oxygen $>5$ $\mathrm{mg} / \mathrm{l}, \mathrm{pH}$ of between 6.0-8.5 ammonia $\left(\mathrm{NH}_{4}{ }^{+}\right)$content $<1 \mathrm{mg} / \mathrm{l}$, photoperiod was natural day light. 
The research was conducted at the Ornamental Fish Farming Unit of the Fisheries Faculty in Sinop University (Sinop, Turkey). Experiments were conducted in 7 groups. The first group was control group (C), the second group was $20 \mathrm{mg} \mathrm{kg}^{-1} 17 \alpha-\mathrm{MT}$ hormone treatment, the third group was $40 \mathrm{mg} \mathrm{kg}^{-1} 17 \alpha-\mathrm{MT}$ hormone treatment, the forth group was $60 \mathrm{mg} \mathrm{kg}^{-1} 17 \alpha$-MT hormone treatment, the fifth group was $20 \mathrm{mg} \mathrm{kg}^{-1}$ $17 \beta$-ES hormone treatment, the sixth group was $40 \mathrm{mg} \mathrm{kg}^{-1} 17 \beta$-ES hormone treatment and the seventh group was $60 \mathrm{mg} \mathrm{kg}^{-1} 17 \beta$-ES hormone treatment (Table 1).

Table 1. Diet groups in trial

\begin{tabular}{c|c|c}
\hline Trial groups & Hormone application & $\begin{array}{c}\text { Dosage } \\
\left(\mathbf{m g ~ k g}^{-1}\right)\end{array}$ \\
\hline 1 & Control diet & No hormone \\
2 & $17 \alpha-\mathrm{MT}$ & 20 \\
3 & $17 \alpha-\mathrm{MT}$ & 40 \\
4 & $17 \alpha-\mathrm{MT}$ & 60 \\
5 & $17 \beta-\mathrm{ES}$ & 20 \\
6 & $17 \beta-\mathrm{ES}$ & 40 \\
7 & $17 \beta-\mathrm{ES}$ & 60 \\
\hline
\end{tabular}

\section{Growth Parameters}

Fish growth performance were calculated according to the following formulas:

$$
\begin{gathered}
\text { Weight gain }(\%)=100 *\left(\mathrm{Wt}-\mathrm{W}_{0}\right) / \mathrm{W}_{0} \\
\text { Specific Growth Rate }\left(\mathrm{SGR}, \% \text { day }^{-1}\right)=100 \times\left(\ln \mathrm{Wt}-\ln \mathrm{W}_{0} / \mathrm{t}\right)
\end{gathered}
$$

where; $\ln =$ Natural logarithm, $\mathrm{W}_{0}=$ initial weight $(\mathrm{g}), \mathrm{Wt}=$ final weight $(\mathrm{g})$ and $\mathrm{t}=$ time in days from stocking to harvesting.

$$
\text { Survival Rate }(\%)=(\text { number of fish harvested/number of fish stocked }) \times 100 \text { (Eq.3) }
$$$$
\text { Feed Conversion Ratio }(\mathrm{FCR})=\text { feed given }(\mathrm{g}) / \text { body weight gain }(\mathrm{g})
$$

The condition factor $(\mathrm{k})$ of the experimental fish was estimated from the relationship:

$$
\mathrm{K}=100 \times\left(\mathrm{w} / \mathrm{L}_{\mathrm{b}}\right)
$$

where; $\mathrm{W}=$ Weight of the fish in grams, $\mathrm{L}=$ The total length of the fish in centimeters, $\mathrm{b}=$ The value obtained from the length-eight equation formula.

\section{Colouration Measurements}

Instrumental color measurement method was used to determine the fish color. For this purpose, a colorimeter (Konica Minolta CR 400) was used to measure skin color parameters $\left(\mathrm{L}^{*}, \mathrm{a}^{*}, \mathrm{~b}^{*}\right.$ values) of the fish samples from the dorsal sections of the fish (CIE, 1986). $\mathrm{C}^{*}$ and $\mathrm{H}_{\mathrm{ab}}{ }^{\mathrm{o}}$ values were calculated by using $\mathrm{a}^{*}$ and $\mathrm{b}^{*}$ values. The following parameters were determined: $\mathbf{L}^{*}:(+)$ brightness, (-) darkness, $\mathbf{a}^{*}:(+)$ redness, (-) greenness, $\mathbf{b}^{*}:(+)$ yellowness, (-) blueness (Nickell and Bromage, 1998). 
Chroma $\left(\mathrm{Cab}^{*}\right)$ indicates intensity and purity of the colors and is calculated with the equation:

$$
\mathrm{C}_{\mathrm{ab}} *=\left(\mathrm{a}^{* 2}+\mathrm{b}^{* 2}\right)^{1 / 2}
$$

Hue angle indicates the relationships among yellowness, greenness and blueness of the color and is calculated with the equations (Hunt, 1977):

$$
\mathrm{H}_{\mathrm{ab}}{ }^{\mathrm{o}}=\tan ^{-1}\left(\mathrm{~b}^{*} / \mathrm{a}^{*}\right) \text { for } \mathrm{a}^{*}>0 \text { and } \mathrm{H}_{\mathrm{ab}}{ }^{\mathrm{o}}=180+\tan ^{-1}\left(\mathrm{~b}^{*} / \mathrm{a}^{*}\right) \text { for } \mathrm{a}^{*<0}
$$

Hue is an angle indicating a red color tone at $0^{\circ}$, yellow color tone at $90^{\circ}$, green color tone at $180^{\circ}$ and blue color tone at $270^{\circ}$ (Nickell and Bromage, 1998; Yeşilayer et al., 2011).

\section{Statistical Calculations}

One-way analysis of variance (ANOVA) was applied to determine the differences in experimental data and the differences in intragroup and intergroup means were calculated with Fisher's test and expressed in mean \pm standard error (mean $\pm \mathrm{SE}$ ). Statistical analysis of the study results was performed with "Minitab Release 17 for Windows" software. In terms of water parameters statistical significance among experimental groups were evaluated by one-way analysis of variance (ANOVA) and means were compared using Fisher's range test at 5\% level of significant.

\section{Results}

Throughout the experiments, temperature, dissolved oxygen, $\mathrm{pH}$ and $\mathrm{NH}_{4}{ }^{+}$values of the aquariums were measured at certain intervals and average water temperature was measured as $26.23 \pm 0.09{ }^{\circ} \mathrm{C}$, dissolved oxygen $\left(\mathrm{O}_{2}\right)$ content was measured as $6.26 \pm 0.07$, $\mathrm{pH}$ as $8.13 \pm 0.03$ and $\mathrm{NH}_{4}{ }^{+}$as $2.4 \pm 0.08 \mathrm{mg} / 1$.

\section{Growth Parameters and Feed Conversion Ratio}

At the end of the experiments, the greatest increase in weight $(\mathrm{g})$, weight gain $(\%)$ and specific growth rate were observed in $20 \mathrm{mg} \mathrm{kg}^{-1} 17 \alpha$-MT group and live weights increased about 1.5-2 folds at the end of 60-day feeding period. On the other hand, growth and feed conversion were negatively influenced in groups fed with high hormone-containing feeds (Table 2). For instance, at the end of the experiments, fish exhibited the least growth in $60 \mathrm{mg} \mathrm{kg}^{-1} 17 \beta$-ES hormone treatments $(\mathrm{P}<0.05)$. At the end of the this research, feed conversion ratios of the treatments were similar with each other and the best conversion ratio was determined in $60 \mathrm{mg} \mathrm{kg}^{-1} 17 \alpha$-MT hormone treatments. Again at the end of the experiments, the best condition factor was determined in $20 \mathrm{mg} \mathrm{kg}^{-1} 17 \beta$-ES hormone treatment group and the differences from the other groups statistically $(\mathrm{P}<0.05)$.

\section{Survival Rates (\%)}

With regard to survival rates at the end of the this research, in both $17 \alpha-\mathrm{MT}$ and $17 \beta$-ES hormone treatments, decreasing survival rates were observed with increasing hormone quantities. The greatest survival rate was determined in $20 \mathrm{mg} \mathrm{kg}^{-1} 17 \alpha-$ 
MT hormone treatments $(86.68 \pm 6.67 \%)$ and the lowest survival rate was determined in $60 \mathrm{mgkg}^{-1} 17 \beta$-ES hormone treatments and a statical difference was found between in the $60 \mathrm{mgkg}^{-1} 17 \beta$-ES hormone group and the other experimental groups $(\mathrm{P}<0.05)$ (Table 2).

\section{Sex Reversal (\%)}

With regard to sex ratios of the groups, it was observed that there were $73.33 \%$ females and $26.67 \%$ males in the control group. In groups treated with testosterone hormone at different ratios (17 $\alpha$-MT 20, 40, $60 \mathrm{mg} \mathrm{kg}^{-1}$ ), all fish (100\%) were composed of male individuals. On the other hand in groups treated with estradiol hormone at different ratios (17ß-ES 20, 40, $60 \mathrm{mg} \mathrm{kg}^{-1}$ ), the greatest ratio was determined in $60 \mathrm{mg} \mathrm{kg}^{-1} 17 \beta$-ES treatment group ( $86.67 \%$ female and $13.33 \%$ male) (Figure 2).

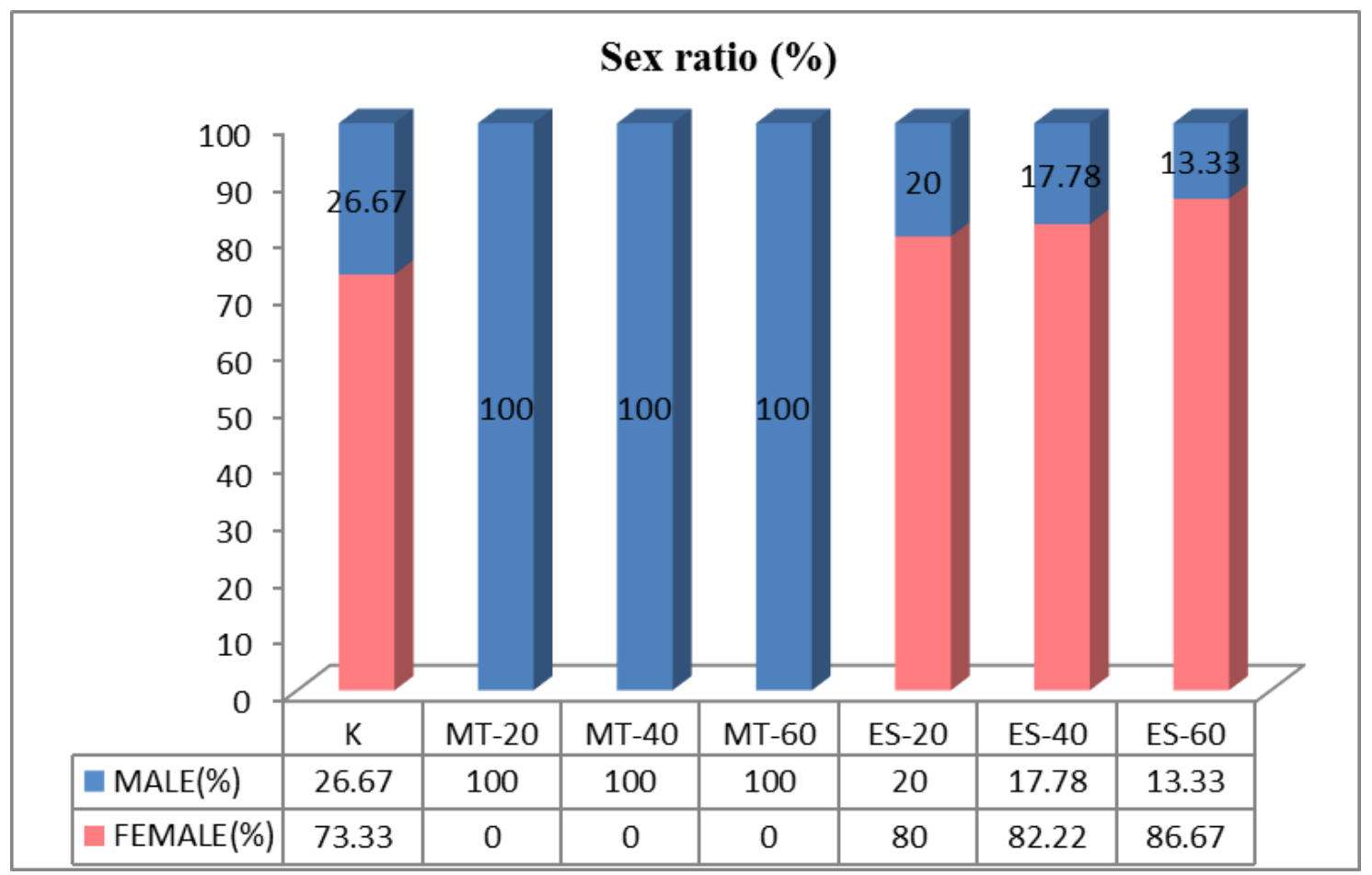

Figure 2. Sex inversion at the end of study (\%)

\section{Color Parameters}

Since the characteristic color of the fish species used in this studs is yellow, $b^{*}$ value was positive in all treatments groups and the greatest $b^{*}$ value was determined in $40 \mathrm{mg}$ $\mathrm{kg}^{-1} 17 \beta$-ES treatments (35.56 \pm 5.92$)$. With regard to $\mathrm{H}_{\mathrm{ab}}{ }^{\mathrm{o}}$ angles of the treatment groups at the end of the experiments (from yellow to red), the greatest angle value was observed in $40 \mathrm{mg} \mathrm{kg}^{-1} 17 \alpha-\mathrm{MT}$ treatment group $(80.90 \pm 1.06)$ and it was respectively followed by $60 \mathrm{mg} \mathrm{kg}^{-1} 17 \alpha-\mathrm{MT}(80.93 \pm 0.65)$ and $20 \mathrm{mg} \mathrm{kg}^{-1} 17 \alpha-\mathrm{MT}(81.12 \pm 1.52)$ treatments (Table 3). 
Table 2. Growth performance, feed conversion ratios (FCR), survival and condition factor of electric yellow cichlid at the end of experiment

\begin{tabular}{|c|c|c|c|c|c|c|c|}
\hline Groups & Control & $\begin{array}{c}20 \mathrm{mg} \\
17 \alpha-\mathrm{MT}\end{array}$ & $\begin{array}{c}40 \mathrm{mg} \\
17 \alpha-\mathrm{MT}\end{array}$ & $\begin{array}{c}60 \mathrm{mg} \\
17 \alpha-\mathrm{MT}\end{array}$ & $\begin{array}{c}20 \mathrm{mg} \\
17 \beta-\mathrm{ES}\end{array}$ & $\begin{array}{c}40 \mathrm{mg} \\
17 \beta-\mathrm{ES}\end{array}$ & $\begin{array}{c}60 \mathrm{mg} \\
17 \beta-\mathrm{ES}\end{array}$ \\
\hline Initial weight (g) & $0.64 \pm 0.01^{\mathrm{a}}$ & $0.64 \pm 0.01^{\mathrm{a}}$ & $0.64 \pm 0.01^{\mathrm{a}}$ & $0.64 \pm 0.01^{\mathrm{a}}$ & $0.64 \pm 0.01^{\mathrm{a}}$ & $0.64 \pm 0.01^{\mathrm{a}}$ & $0.64 \pm 0.01^{\mathrm{a}}$ \\
\hline Final weight (g) & $0.89 \pm 0.18^{\mathrm{cd}}$ & $1.03 \pm 0.10^{\mathrm{a}}$ & $0.97 \pm 0.24^{\mathrm{ab}}$ & $1.00 \pm 0.14^{\mathrm{ab}}$ & $0.91 \pm 0.15^{\text {cd }}$ & $0.94 \pm 0.31^{\mathrm{bc}}$ & $0.87 \pm 0.24^{\mathrm{d}}$ \\
\hline Weight increase (g) & $0.24 \pm 0.05^{\mathrm{cd}}$ & $0.39 \pm 0.17^{\mathrm{a}}$ & $0.33 \pm 0.11^{\mathrm{ab}}$ & $0.35 \pm 0.08^{\mathrm{ab}}$ & $0.26 \pm 0.12^{\text {cd }}$ & $0.30 \pm 0.06^{\text {bc }}$ & $0.23 \pm 0.11^{\mathrm{d}}$ \\
\hline Weight gain $(\%)$ & $37.40 \pm 7.95^{\mathrm{cd}}$ & $59.90 \pm 27.2^{\mathrm{a}}$ & $50.50 \pm 17.3^{\mathrm{ab}}$ & $54.85 \pm 13.12^{\mathrm{ab}}$ & $39.70 \pm 18.3^{\text {cd }}$ & $46.21 \pm 8.92^{\mathrm{bc}}$ & $34.93 \pm 16.81^{\mathrm{d}}$ \\
\hline SGR $^{*}$ & $0.53 \pm 0.09^{\text {cd }}$ & $0.77 \pm 0.29^{\mathrm{a}}$ & $0.67 \pm 0.19^{\mathrm{ab}}$ & $0.73 \pm 0.14^{\mathrm{ab}}$ & $0.55 \pm 0.22^{\text {cd }}$ & $0.63 \pm 0.09^{\mathrm{bc}}$ & $0.49 \pm 0.20^{\mathrm{d}}$ \\
\hline FCR & $3.72 \pm 0.59^{\mathrm{a}}$ & $2.97 \pm 1.28^{\mathrm{b}}$ & $2.99 \pm 1.02^{\mathrm{b}}$ & $2.56 \pm 0.49^{\mathrm{b}}$ & $3.61 \pm 0.97^{\mathrm{a}}$ & $2.82 \pm 0.44^{\mathrm{b}}$ & $3.80 \pm 1.01^{\mathrm{a}}$ \\
\hline Survival rate $(\%)$ & $82.23 \pm 3.87^{\mathrm{a}}$ & $86.68 \pm 6.67^{\mathrm{a}}$ & $64.43 \pm 7.68^{\mathrm{c}}$ & $62.20 \pm 10.18^{c}$ & $73.3 \pm 23.1^{\mathrm{b}}$ & $66.67 \pm 6.65^{\mathrm{bc}}$ & $53.3 \pm 17.7^{\mathrm{d}}$ \\
\hline Condition factor & $1.22 \pm 0.03^{\mathrm{c}}$ & $1.22 \pm 0.04^{\mathrm{c}}$ & $1.26 \pm 0.09^{\mathrm{bc}}$ & $1.26 \pm 0.02^{\mathrm{bc}}$ & $1.37 \pm 0.19^{\mathrm{a}}$ & $1.27 \pm 0.05^{\mathrm{b}}$ & $1.26 \pm 0.03^{\mathrm{bc}}$ \\
\hline
\end{tabular}

Values (mean \pm SE) with different superscripts in the same row are significantly different at the $5 \%$ level

*Specific growth rates

Table 3. Colouration ( $L, a, b, C a b *$ and $H_{a b}{ }^{\circ}$ ) measurements of juvenile electric yellow cichlid (Labidochromis caeruleus Fryer, 1956) at the end of the experiment

\begin{tabular}{|c|c|c|c|c|c|c|c|c|}
\hline \multirow[b]{2}{*}{$\begin{array}{c}\text { Colour } \\
\text { parameters }\end{array}$} & \multirow[b]{2}{*}{$\begin{array}{c}\text { Initial } \\
\text { parameters }\end{array}$} & \multicolumn{7}{|c|}{ Groups and end of experiments } \\
\hline & & Control & $\begin{array}{c}20 \mathrm{mg} \\
17 \alpha-\mathrm{MT}\end{array}$ & $\begin{array}{c}40 \mathrm{mg} \\
17 \alpha-\mathrm{MT}\end{array}$ & $\begin{array}{c}60 \mathrm{mg} \\
17 \alpha-\mathrm{MT}\end{array}$ & $\begin{array}{c}20 \mathrm{mg} \\
17 \beta-\mathrm{ES}\end{array}$ & $\begin{array}{c}40 \mathrm{mg} \\
17 \beta-\mathrm{ES}\end{array}$ & $\begin{array}{c}60 \mathrm{mg} \\
17 \beta-\mathrm{ES}\end{array}$ \\
\hline $\mathbf{L}^{*}$ & $67.48 \pm 0.95^{\mathrm{ab}}$ & $69.27 \pm 1.29^{\mathrm{a}}$ & $68.23 \pm 3.20^{\mathrm{ab}}$ & $67.51 \pm 0.26^{\mathrm{ab}}$ & $64.82 \pm 4.89^{\mathrm{b}}$ & $69.08 \pm 2.90^{\mathrm{ab}}$ & $71.64 \pm 1.06^{\mathrm{a}}$ & $71.27 \pm 1.56^{\mathrm{a}}$ \\
\hline $\mathbf{a}^{*}$ & $-0.51 \pm 0.01^{\mathrm{c}}$ & $2.36 \pm 0.24^{\mathrm{b}}$ & $3.81 \pm 0.31^{\mathrm{a}}$ & $3.76 \pm 0.25^{\mathrm{a}}$ & $4.23 \pm 0.64^{\mathrm{a}}$ & $2.72 \pm 0.34^{\mathrm{b}}$ & $2.71 \pm 0.29^{\mathrm{b}}$ & $2.91 \pm 0.22^{\mathrm{b}}$ \\
\hline $\mathbf{b}^{*}$ & $12.98 \pm 0.12^{\mathrm{d}}$ & $33.43 \pm 4.61^{\mathrm{ab}}$ & $25.90 \pm 1.05^{\mathrm{c}}$ & $24.52 \pm 1.92^{\mathrm{c}}$ & $26.73 \pm 2.10^{\mathrm{c}}$ & $27.65 \pm 1.28^{\mathrm{c}}$ & $35.56 \pm 5.92^{\mathrm{a}}$ & $28.06 \pm 3.19^{\mathrm{bc}}$ \\
\hline Hue $\left(\mathrm{H}_{a b}{ }^{\circ}\right)$ & $92.44 \pm 0.08^{\mathrm{a}}$ & $85.70 \pm 0.52^{\mathrm{b}}$ & $81.12 \pm 1.52^{\mathrm{d}}$ & $80.90 \pm 1.06^{\mathrm{d}}$ & $80.93 \pm 0.65^{\mathrm{d}}$ & $84.26 \pm 0.55^{\mathrm{c}}$ & $84.05 \pm 0.59^{\mathrm{c}}$ & $83.86 \pm 0.35^{\mathrm{c}}$ \\
\hline $\mathbf{C a b}^{*}$ & $13.06 \pm 0.07^{\mathrm{d}}$ & $31.20 \pm 0.65^{\mathrm{a}}$ & $26.23 \pm 0.97^{\mathrm{bc}}$ & $24.89 \pm 1.88^{\mathrm{c}}$ & $27.09 \pm 2.17^{\mathrm{bc}}$ & $27.69 \pm 1.31^{\mathrm{b}}$ & $26.86 \pm 2.74^{\mathrm{bc}}$ & $27.67 \pm 1.19^{\mathrm{b}}$ \\
\hline
\end{tabular}

Values (mean $\pm \mathrm{SE}$ ) with different superscripts in the same row are significantly different at the $5 \%$ level

Hue $\left(\mathrm{H}_{\mathrm{ab}}{ }^{\circ}\right)$, chroma $\left(\mathrm{Cab}^{*}\right)$, lightness $\left(\mathrm{L}^{*}\right)$, redness $\left(\mathrm{a}^{*}\right)$, yellowness $\left(\mathrm{b}^{*}\right)$ 


\section{Discussion}

In this study, effects of $17 \alpha$-Metiltestosteron and $17 \beta$-Estradiol hormones on growth, development, survival rate, sex reversal and color parameters of cichlid fish

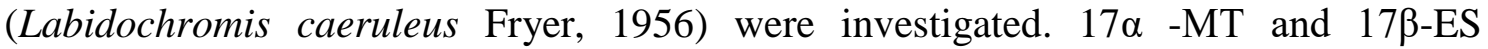
hormones were used in this study because of they are the most effective anabolic steroids for fish (Turan et al., 2003).

Physical (instrumental) color analyses were performed on fish before and after the experiments. Physical color analysis is particularly important in determining the color of the ornamental fish skin and is an objective method far from subjectivity. At the beginning of this research, fish skin colors were found in yellow-grey tones according to the initial Hue $\left(\mathrm{H}_{\mathrm{ab}}{ }^{\circ}\right)$ angles, since the fish were used and the pigmentation did not start at the beginning of the experiments.

According to physical color analysis at the end of the experiments, the best coloration was determined in 17 $\alpha$-MT hormone treatments, coloration increased with increasing hormone doses and the differences from the other groups were found to be significant. Significant differences were also observed between the control and 17 $\beta$-ES hormone groups. Significant differences were also determined in color changes according to the beginning of experiment of all experiment groups. Larsson et al., (2002) found more reddish tail coloration of guppies from the $8^{\text {th }}$ day of experiments with 17 $\alpha$-MT treatments and determined significant differences from the control group from the $17^{\text {th }}$ day of experiments. In addition, Keskin (2005) reported the initiation of color formation of guppies from the $3^{\text {rd }}$ week of experiments with $17 \alpha$-MT hormone. Jessy and Varghese (1987) also reported increasing body coloration of Beta splendens and Xiphophorus helleri species with 17 $\alpha$-MT hormone treatments. Otherwise, Kayim (1997) and Turan (2001) reported that this hormone increases pigmentation and has a positive effect on skin colouration.

The $\mathrm{b}^{*}$ values $(+)$ of the control and 17ß-ES hormone treatment groups were greater than the $b^{*}$ values of $17 \alpha-\mathrm{MT}$ hormone groups and closer to yellow color. Slightly better coloration of $17 \alpha$-MT hormone groups was because all fish in these groups became male and males of this species have more brilliant colors as compared to the females. Karsli et al. (2016) investigated the effects of 17 $\beta$-ES and 17 $\alpha$-MT hormones on coloration of Sciaenochromis ahli species and differences were reported in fish coloration based on type and dose of hormones. The $b^{*}$ values were all negative (-) in $17 \alpha$-MT hormone groups. The lowest $\mathrm{b}^{*}$ value was determined in $60 \mathrm{mg} \mathrm{kg}^{-1} 17 \alpha-\mathrm{MT}$ hormone treatment and it was respectively followed by $40 \mathrm{mg} \mathrm{kg}^{-1}$ and $20 \mathrm{mg} \mathrm{kg}^{-1} 17 \alpha-$ MT hormone treatments. The $b^{*}$ values of the control and 17 $\beta$-ES hormone treatments were all positive $(+)$. Yeşilayer et al. (2011) investigated the effects of various carotenoid sources on skin color of Carassius auratus species and reported greater $\mathrm{a}^{*}$ values for experimental groups, thus indicated darker red tones with carotenoid sources than the control treatments. Researchers also indicated based on carotenoid sources that $b^{*}$ values were positive (+) and all of experimental groups had low $\mathrm{H}_{\mathrm{ab}}{ }^{\mathrm{o}}$ values. On the other hand, Yanong et al. (2006) fed swordtails fry with 17a-MT hormone diets for 28 days and continued the observations until the $6^{\text {th }}$ month and reported that there were not any significant differences in coloration of the experimental groups.

The differences in growth parameters of the experiments statistically significant $(\mathrm{P}<0.05)$. George and Pandian (1996) reported that the study on zebra cichlid species 
shows a decrease in the growth of fish at doses higher than $100 \mathrm{mg} \mathrm{kg}^{-1}$ of $17 \beta$-ES and $400 \mathrm{mg} \mathrm{kg}^{-1}$ of $17 \alpha-\mathrm{MT}$. Karsli et al. (2016) in a study with Sciaenochromis ahli species, used different doses of $17 \beta$-ES and $17 \alpha$-MT hormones and indicated that $17 \alpha-$ MT hormone groups exhibited better growth than the $17 \beta$-ES hormone groups and the differences in growth performance of treatment groups were significant. Carhalvo et al. (2014) used two different doses of $\left(50,100 \mathrm{mg} \mathrm{kg}^{-1}\right)$ of $17 \beta$-ES hormone on growth of Centropomus undecimalis and the differences in growth of control group than experimental groups were significant. Lim et al. (1992) indicated that five different doses of $17 \alpha-$ MT and 17 -ES hormones (50, 100, 200, 500 and $750 \mathrm{mg} \mathrm{kg}^{-1}$ ) did not have any significant effects on growth parameters of swordtails. Tamaru et al. (2009) carried out a study again with swordtails and the optimum dose for feminization was $400 \mathrm{mg} \mathrm{kg}-1$ and reported that there was no adverse effect on growth. The results obtained in this study different from the above studies. Feed conversion ratio is a significant parameter with direct impacts on operational costs of the growers based on the feed quantities of feed consumed by the fish. Kayım (1997) found that 17 $\alpha$-MT hormone treatment had positive effects on feed conversion rates in sword tail and by Karsli et al. (2016) in Sciaenochromis ahli species. Güzel et al. (2006) carried out a study with trout and indicated that $17 \beta$-ES hormone had not any significant effects of feed conversion ratio. Accordingly, 17 $\alpha$-MT hormone treatments had more positive effects on feed conversion ratios than the $17 \beta$-ES hormone treatments. Contrary to the present study, Smith and Phelps (2001) reported that 17 $\alpha$-MT hormone treatments have non-significant effects on feed conversion ratios of the Nile tilapia.

Considering the survival ratios of the fish, these two hormones had negative effects on survival specially at higher rates. George and Pandian (1996) applied two different hormones on zebra cichlids and indicated decreasing survival rates at higher doses. Tamaru et al. (2009) used five different doses of $17 \beta$-ES hormone on swordtails and indicated the optimum dose as $400 \mathrm{mg} \mathrm{kg}^{-1}$ and carried out the lowest survival rate in $200 \mathrm{mg} \mathrm{kg}^{-1}$ treatment and also indicated that the differences from the other groups were significant. Carhalvo et al. (2014) used two different doses of $\left(50,100 \mathrm{mg} \mathrm{kg}^{-1}\right)$ of $17 \beta$ ES hormone on survival rate of Centropomus undecimalis and found that the differences of all experimental groups were nonsignificant.

In a study carried out with Poecilia sphenops species known as black molly in ovoviviparous fish, George and Pandian (1998) applied different 17 $\alpha$-MT doses and reported important decreases in survival rates at doses over $200 \mathrm{mg} \mathrm{kg}^{-1}$. Das et al. (2010) applied 17 $\alpha$-MT hormones at different doses $\left(15,30,60,120 \mathrm{mg} \mathrm{kg}^{-1}\right)$ for 3 weeks on Tilapia fry and found the survival rates of experimental groups as $92.45 \%$, $95.41 \%, 93.75 \%$ and $89.00 \%$ respectively. Çelik (2002) applied five different doses (20, $30,40,50,60 \mathrm{mg} \mathrm{kg}^{-1}$ ) of $17 \alpha-\mathrm{MT}$ hormone to Oreochromis niloticus and reported the greatest survival rate for $40 \mathrm{mg} \mathrm{kg}^{-1} 17 \alpha-\mathrm{MT}$ hormone group and the lowest survival rate for $50 \mathrm{mg} \mathrm{kg}^{-1} 17 \alpha-\mathrm{MT}$ hormone treatment. Kayım (1997) reported the survival rates of $17 \alpha$-MT hormone-treated swordtails as $100 \%$.

With regard to sex ratios at the end of the experiments, it was determined in control group that $73.33 \%$ of the fish were female and $26.67 \%$ were male. In treatment groups with estradiol hormone (17 $\beta$-ES) at different doses, the best sex reversal was determined in $60 \mathrm{mg} \mathrm{kg}^{-1} 17 \beta$-ES hormone treatments ( $86.67 \%$ female, $13.33 \%$ male). On the other hand, in treatment groups with testosterone hormone (17 $\alpha-\mathrm{MT})$ at different doses, all of the fish $(100 \%)$ were male. It was observed that $17 \alpha$-MT hormone was successful in sex reversal at all doses. Besides, it was through that $17 \beta$-ES hormone 
could also increase the success ratio in sex reversal at higher doses, but mortality rates could also increase with increasing hormone doses, thus such negative impacts limited the increase in hormone dose. Tamaru et al. (2009) used different doses of 17ß-ES hormone to swordtails and reported the optimum dose for feminization as $400 \mathrm{mg} \mathrm{kg}^{-1}$ $17 \beta$-ES (97\%). In the same study, female ratio of the control group was reported as $74.5 \%$.

Jessy and Varghese (1987) applied 17 $\alpha$-MT hormone to Beta splendens and Xiphophorus helleri species and determined the greatest male ratio (90.9\%) in $120 \mathrm{mg}$ $\mathrm{kg}^{-1} 17 \alpha$-MT treatment group. James and Sampaty (2006) used different doses of $17 \alpha-$ MT hormone and reported the male ratio as $100 \%$ for 20,40 and $60 \mathrm{mg} \mathrm{kg}^{-1} 17 \alpha-\mathrm{MT}$ treatment groups of $B$. splendes and for $40,60 \mathrm{mg} \mathrm{kg}^{-1} 17 \alpha$-MT treatment groups of $X$. helleri. Kiporus et al. (2011) also reported $100 \%$ male ratio for 2,3 and $4 \mathrm{mg} \mathrm{kg}^{-1} 17 \alpha-$ MT treatment groups of $B$. splendes species, reported $90 \%$ male ratio for $1 \mathrm{mg} \mathrm{kg}^{-1}$ hormone treatment group and $60 \%$ for the control group. Lim et al. (1992) reported that 500 and $750 \mathrm{mg} \mathrm{kg}-117 \alpha-\mathrm{MT}$ hormones were effective in production of males sword tail population, while 500 and $750 \mathrm{mg} \mathrm{kg}^{-1} 17 \beta$-ES hormones were effective in production of females sword tail population. In addition, they indicated that singlesexed populations would occur when high doses of both hormones $\left(750 \mathrm{mg} \mathrm{kg}^{-1}\right)$ were administered for 30 days. Similarly, George and Pandian (1996) applied two different hormones on zebra cichlids and determined the greatest male ratio in $200 \mathrm{mg} \mathrm{kg}^{-1} 17 \alpha-$ MT treatments (55\%) and the greatest female ratio in $200-300 \mathrm{mg} \mathrm{kg}^{-1} 17 \beta$-ES treatments (100\%). George and Pandian (1998), reported the best sex reversal for Poecilia sphenops species in $50 \mathrm{mg} \mathrm{kg}^{-1} 17 \alpha-\mathrm{MT}$ hormone treatment group. Turan (2001) used $17 \alpha$-MT hormone to guppies and reported the greatest male ratio $(75.7 \%)$ for $60 \mathrm{mg} \mathrm{kg}^{-1}$ hormone treatment. Sezgi and Berkcan (2008) applied $60 \mathrm{mg} \mathrm{kg}^{-1} 17 \alpha-$ MT hormone to tilapia for 28 days from the first day of feeding and obtained $100 \%$ male population. Similarly in the same fish species, Das et al. (2010) used 17 $\alpha$-MT hormone and reported the greatest male ratio $(96 \%)$ for $60 \mathrm{mgkg}^{-1}$ hormone treatment. Shen et al. (2015) reported that 20, 50 and $100 \mathrm{mg} \mathrm{kg}^{-1} 17 \alpha-\mathrm{MT}$ hormone were not effective in male Pelteobagrus fulvidraco ratio.

\section{Conclusion}

It was concluded based on present findings on this fish species that $17 \alpha-\mathrm{MT}$ hormone could provide advantages for better growth, feed conversion ratio and coloration. In this way, fish may reach to marketable size with fewer feed consumption, thus productions costs could be reduced and alluring fish with desired colors could be obtained.

Two hormones which used in this study have positive and negative effects on electric yellow cichlid (Labidochromis caeruleus Fryer, 1956), but considering the effect on growth, development, feed evaluation, coloration, sex and survival rate of $60 \mathrm{mg} \mathrm{kg}^{-1}$ $17 \alpha$-MT hormone and $40 \mathrm{mg} \mathrm{kg}^{-1} 17 \beta$-ES hormone groups were determined to be appropriate dose amounts for this species. In addition, it is thought that the use of different doses of $17 \alpha-\mathrm{MT}$ and $17 \beta$-ES hormones for cichlid species will be useful in subsequent studies.

Acknowledgements. We would like to express our appreciation to the Sinop University Scientific Research Project Commission, which supported this study (SUBAP-MYO 1901-16-21). 


\section{REFERENCES}

[1] Brzuska, E. (1999): Artificial spawning of herbiyorous fish use of an LHRH-a to induce ovulation in Grass Carp Ctenopharryngodon idella (Valenciennes) and Silver Carp Hypophthalmichthys molitrix (Valenciennes). - Aquaculture Research 30: 849-856.

[2] Carvalho, C. V. A., Passini, G., Melo Costa, W., Vieiral, B. N., Cerqueira, V. R. (2014): Effect of estradiol-17 $\beta$ on the sex ratio, growth and survival of juvenile common snook (Centropomus undecimalis). - Acta Scientiarum 36 (3): 239-245. Doi: 10.4025/actascianimsci.v36i3.22839.

[3] CIE (Commission Internationale de 1' Eclairage) (1986): The commonly used data on color matching functions is available at the CIE. CIE publication No: 15.2.

[4] Çelik, I. (2002): Effect of 17-Alpha Methyltestosterone on Growth and Sex Reserval of Nile Tilapia (Oreochromis niloticus L. 1758). MSc Thesis. - Ege University, İzmir, Turkey (In Turkish).

[5] Das, N. G., Mamun, F. A., Barua, P., Siddique, A. A. M., Chowdhury, S. N. (2010): Survivality of mono-sex Tilapia (Oreochromis niloticus) fry using 17 $\alpha$-Methyltestosterone in a commercial hatchery of chittagong, Bangladesh. - Journal of Aquaculture Feed Science and Nutrition 2: 16-24.

[6] George, T., Pandian, T. J. (1996): Hormonal induction of sex reversal and progeny testing in the zebra cichlid Cichlasoma nigrofasciatum. - Journal of Experimental Zoology 275: 374-382.

[7] George, T., Pandian, T. J. (1998): Dietary administration of androgens induces sterility in the female-heterogametic black molly, Poecilia sphenops (Cuvier and Valenciennes, 1846). - Aquaculture Research 29: 167-175.

[8] Güzel, S., Özden, O., Güllü, K. (2006): The effect of Estradiol valerate administration on growth of rainbow trout, Oncorhynchus mykiss. - Research Journal of Animal and Veterinary Sciences 1: 59-61.

[9] James, R., Sampaty, K. (2006): Effect of dietary administration of methyltestosterone on the growth and sex reversal of two ornamental fish species. - Indian Journal of Fisheries 53: $283-290$.

[10] Jessy, D., Warghese, T. J. (1987): Hormonal sex control in Betta splendens Regan and Xiphophorus helleri Heckel. - In: Joseph, M. M. (ed.) The First Indian Fisheries Forum Proceeding, December 4-8, 1987, Mangalore, Karnataka, pp. 123-124.

[11] Karsli, Z., Aral, O., Yeşilayer, N. (2016): The effects of different proportions of the 17ßestradiol and 17 $\alpha$-methyltestosterone on growth, sex reversal and skin colouration of the electric blue hap (Sciaenochromis ahli Trewavas, 1935). - Aquaculture Research 47: 640648. doi:10.1111/are.12524.

[12] Kayım, M. (1997): The Effects of $17 \alpha$-Methyltestosterone on the Growth Characteristics of Swordtail (Xiphophorus helleri H. 1848). MSc Thesis. - Ege University, İzmir, Turkey (In Turkish).

[13] Keskin, E. Y. (2005): The Effect of Hormone Usage on Coloration and Reproduction of Guppy (Poecilia reticulata Peters, 1860) fish. PhD thesis. - Ondokuz Mayıs University, Samsun, Turkey (In Turkish).

[14] Kipouros, K., Paschos, I., Gouva, E., Ergolavou, A., Perdikaris, C. (2011): Masculinization of the ornamental Siamese fighting fish with oral hormonal administration. - ScienceAsia 37: 277-280.

[15] Kop, A., Durmaz, Y. (2008): The effect of synthetic and natural pigments on the color of the cichlids (Cichlasomaseverum sp., Heckel 1840). - Aquac. Int. 16: 117-122.

[16] Larsson, D. G. J., Kinnberg, K., Sturve, J., Stephensen, E., Skön, M., Förlin, L. (2002): Studies of masculinization, detoxification and oxidative stres responses in guppies (Poecilia reticulata) exposed to effluent from a pulp mill. - Ecotoxicology and Environmental Safety 52: $13-20$. 
[17] Lewis, D. S. C. (1982): A revision of the genus Labidochromis (Teleostei: Cichlidae) from Lake Malawi. - Zoological Journal of Linnean 75: 189-262.

[18] Lim, B. H., Phang, V. P. E., Reddy, P. K. (1992): The effect of short-term treatment of $17 \alpha$ -Methyltestosterone and $17 \beta$-Estradiol on growth and sex ratio in the red variety of swordtail, Xiphophorus helleri. - Journal of Aquaculture in the Tropics 7: 267-274.

[19] Nickell, D. C., Bromage, N. R. (1998): The effect of dietary lipid level on variation of flesh pigmentation in rainbow trout(Oncorhynchus mykiss). - Aquaculture 161: 237-251.

[20] Pandian, T. J., Kirankumar, S. (2003): Recent advances in hormonal induction of sex reversal in fish. - Journal of Applied Aquaculture 13: 3-4, 205-230.

[21] Pandian, T. J., Sheela, S. G. (1995): Hormonal induction of sex reversal in fish. Aquaculture 138: 1-22.

[22] Penning, M., Reid, G. McG., Koldewey, H., Dick, G., Andrews, B., Arai, K., Garratt, P., Gendron, S., Lange, J., Tanner, K., Tonge, S., Van den Sande, P., Warmolts, D., Gibson, C. (2009): Turning the Tide: A Global Aquarium Strategy for Conservation and Sustainability. - World Association of Zoos and Aquariums Bern, Switzerland.

[23] Raghavan, R., Dahanukar, N., Tlusty, M., Rhyne, A., Kumar, K., Molur, S., Rosser, A. (n.d) (2013): Uncovering an obscure trade: Threatened freshwater fishes and the aquarium pet markets. - Biological Conservation 164: 158-169.

[24] Rhyne, A. L., Tlusty, M. F., Schofield, P. J., Kaufman, L., Morris, J. A. Jr. (2012): Revealing the Appetite of the Marine Aquarium Fish Trade: The Volume and Biodiversity of Fish Imported into the United States. - PLoS ONE 7(5): e35808. doi:10.1371/journal.pone.0035808.

[25] Saxby, A., Adams, L., Snellgrove, D., Wilson, R. W., Sloman, K. A. (2010): The effect of group size on the behaviour and welfare of four fish species commonly kept in home aquaria. - Applied Animal Behaviour Science 125 (3-4): 195-205. DOI: 10.1016/j.applanim.2010.04.008.

[26] Sezgi, H. B., Bekcan, S. (2008): Farklı periyotlarda 17 $\alpha$ - metiltestosteron ile beslemenin tilapya balıklarının (Oreochromis niloticus L.) cinsiyet dönüşümü üzerine etkileri. -Ankara Üniversitesi Ziraat Fakültesi Tarım Bilimleri Dergisi 14 (3): 222-229.

[27] Shen, Z-G., Fan, Q-X., Yang, W., Zhang, Y-L., Wang, H-P. (2015): Effects of 17_Methyltestosterone and Aromatase Inhibitor Letrozole on Sex Reversal, Gonadal Structure, and Growth In Yellow Catfish Pelteobagrus fulvidraco. - Biol. Bull. 228: 108-117.

[28] Smith, E. S., Phelps, R. P. (2001): Impact of feed storage conditions on growth and efficacy of sex reversal of Nile Tilapia. - North American Journal of Aquaculture 63: 242-245.

[29] Şahin, Y. (1999): A'dan Z'ye Akvaryum. - İnkılap Press, İstanbul, Turkey, 320 pp (in Turkish).

[30] Tamaru, C. S., Yamasaki, L. S., McGovern-Hopkins, K., Malecha, S., Vincent, D. (2009): Feminization of Commercial swordtails, Xiphophorus helleri, by dietary administration of $17 \beta$-Estradiol. Aqua tips. - Center for Tropical and Subtropical Aquaculture Available at: FeminizingSwordtails633806780645168 749.pdf.

[31] Turan, F. (2001): Farklı düzeylerde suya ve yeme katılan androjen hormonunun (17 $\alpha$ metiltestosteron) lepistes balıklarında (Poecilia reticulata) cinsiyet dönüşümü ve büyüme üzerine etkileri. - Yüksek Lisans Tezi. Mustafa Kemal Üniversitesi, Fen Bilimleri Enstitüsü. Antakya, $69 \mathrm{~s}$.

[32] Turan, F., Akyurt, İ., Çek, Ş., Yıldırım, Y., Turan, C. (2003): Hormonal Applications in Fish Production. - XII. National Aquaculture Symposium, 2-5 September, Elazığ, Turkey (in Turkish).

[33] Yanong, R. P. E., Hill, J. E., Daniels, C. J., Watson, C. A. (2006): Efficacy of 17 $\alpha$ Methyltestosterone for expression of male secondary sexual characteristics in the green swordtail. - North American Journal of Aquaculture 68: 224-229.

[34] Yeşilayer, N., Aral, O., Karsl1, Z., Öz, M., Karaçuha, A., Yağc1, F. (2011): The effect of different carotenoid sources on skin pigmentation of goldfish (Carassius auratus). - The Israeli Journal of Aquaculture-Bamidgeh 63: 1-9. 